\title{
Colonial American Fitzpatrick Settlers Part I: Making Sense of One Line
}

\author{
by lan Fitzpatrick ${ }^{1, *} \square$ and Mike Fitzpatrick ${ }^{2} \square$ \\ ${ }^{1}$ Genealogist, Newmarket L3Y 7C9, Canada \\ 2 Independent Scholar, Auckland 0604, New Zealand \\ *Author to whom correspondence should be addressed
}

Journal of the Fitzpatrick Clan Society 2020, 1, 18-39

\begin{abstract}
Before the turn of the 17th century the settlement of Irish in the Americas lacked permanence. Soon after, Irish came to North America and the Caribbean in a steady flow, and by the mid 18th century a flood of Irish and Scotch-Irish had settled in the Americas. The reasons for that settlement were many and varied, as were the geographic origins and lineages of those Fitzpatricks among the influx. This article provides a review of the forces that pushed and pulled Irish and Scotch-Irish to the Americas. By way of example, a single Fitzpatrick line demonstrates how messy traditional genealogy of early Colonial American Fitzpatricks can get. That messiness is due in no small part to the cut and paste functionality at websites such as ancestry.com. But by careful review of authentic historical records, caution with speculative associations, and the power of Y-DNA analysis, it is possible to untangle the mess and bring back some much-needed clarity. In this article, the example used is that of the well-known colonial-settler William Fitzpatrick (born ca. 1690 AD), of Albemarle County, Virginia, who arrived in North American ca. 1728. Two living ancestors of William have been found to share a common ancestry from ca. 1650 AD - both bear a genetic mutation (FT15113) specific to William's line; this enables the ready identification of male descendants of William.
\end{abstract}

\section{A Note on Styles, Edits, and DNA lingo}

This article is written in the English language, but some of the places discussed are Irish. To acknowledge the primacy of Gaeilge (Gaelic) in this article and to promote its use, the Irish place names are provided in modern Gaeilge.

Quotations are italicised, and long or textually significant quotations are also indented.

This article is a living work, i.e., it can be edited by the authors; all versions will be retained.

For a useful Y-DNA guide and DNA lingo for beginners, visit www.fitzpatrickclan.org.

The Journal uses a convention that identifies an individual's haplotype by defining them with Single Nucleotide Polymorphisms (SNPs), typically as follows: the main branch SNP, the Fitzpatrick surname-specific SNP (if there is one), and the individual's terminal SNP, for example, FGC11134...BY12234...FT15113.

\section{Introduction}

From the early days of the Fitzpatrick Y-DNA project it was evident there was no single genetic Fitzpatrick patrilineage, rather several larger haplogroups were identified based on analysis of Y-DNA Short Tandem Repeats (STRs), which were broadly associated with either Counties, such as An Cabhán (Co. Cavan), An Dún (Co. Down), or Laois (Co. Laois) (Fitzpatrick, 2005). Today the complexity of Fitzpatrick Y-DNA lines is soundly understood (Fitzpatrick \& Fitzpatrick, 2020) and yet an understanding of how the Fitzpatrick surname, long 
considered a patronymic from a sole progenitor, came into the possession of numerous and diverse patrilineages is limited.

Of almost singular focus concerning Y-DNA surname projects, particularly those surnames of Irish or Scottish origins, has been the quest to identify a genetic homeland or a clan chief; the geographic location where the clan founder or some ancestor of note lived and breathed (Fitzpatrick \& Fitzpatrick, 2020). Such projects are rarely straight forward, and the Fitzpatrick Y-DNA project is an instant case in point - members may at times face a baffling array of matches with Fitzpatricks from disparate locations in Ireland and across the globe, as well as matches with other surnames. Multiple Y-DNA matches, coupled with the well-known limitations of Irish genealogical records (Grenham, 2019), add considerable complexity to any attempts to unravel a Fitzpatrick past.

This article is the first in a series examining the origins of, and connections between, one of the large Y-DNA haplogroups on the Fitzpatrick DNA project (FamilyTreeDNA, 2020), viz., FGC11134...BY12234 (Figure 1), who trace to the United States of America from earliest times of settlement, i.e., ca. 1700 AD. To set the scene is a single Colonial American Fitzpatrick lineage. Although research on this line is still in its early stages it is useful to provide a status report of the findings at this juncture because (a) it serves to demonstrate one approach to uncovering Fitzpatrick origins; (b) it offers the opportunity to critique genealogical practices; (c) by reporting some of the discoveries others will be encouraged to become interested in exploring their genetic tree; and, (d) genealogy is not for the impatient - many Fitzpatricks have been waiting for years for any results from the investment they made in DNA testing, which could provide new insights into their roots.

Colonial American Fitzpatrick Settlers, Part I: Making Sense of One Line begins with an overview of the factors which led to the migration of Irish to the Americas during the Colonial period, i.e., the period between the arrival of Cristoffa Corombo (Christopher Columbus) in 1492 until 1763 (Library of Congress, 2020). The latter date marks the end of the French and Indian War in North America, the signing of the Treaty of Paris - in which France ceded most of its mainland North American territories - and the proclamation of George III of Great Britain that forbad, 'on Pain of our Displeasure, all our loving Subjects from making any Purchases or Settlements whatever,' west of the Appalachian mountains (George III, 1763).

For this series of articles, the practical commencement of the Colonial period, as it relates to migration from Ireland, is from the early 17th century, since the arrival of Irish was numerically insignificant until after the settlement of the Colony of Virginia in 1607. Although fishermen, including Irish, had used bases, such as Ferryland, around southeast Newfoundland from the late 16th century, there was no permanence of settlement (Sweeny, 2006). When Irish began settling the Americas' shores in more significant numbers, it was first in the Guianas ca. 1612 (Gwynn, 1929a). Virginia followed in November 1621 with the arrival of Master Gookin out of Ireland, with fifty men of his owne, and thirty passengers, exceedingly well furnished with all sorts of provision and cattle (Smith, 1907). Irish migration to Massachusetts is recorded from 1623, but the growth of the Irish community was not steady until 1633 (Donovan, 1932). And in 1626, Irish adventurers joined Englishman John Hilton's tobacco trade venture on St Kitts, then the most important early settlement of the English in the Caribbean; Irish immigration to the Caribbean was constant from that time (Gwynn, 1932a).

The key to uncovering the origins of Fitzpatricks, who emigrated from Ireland during the American Colonial period, is an understanding of the various factors that resulted in Irish migration. What was the political and socio-economic climate in Ireland at that time? What was the religion of the migrants? What were their occupations, and who were their associates? These factors are well understood in the general context of Irish migration, and there is no single answer. But by seeking those answers as they pertain to individuals much can be learned about who those Fitzpatrick American Colonists were; remarkably, uncovering their likely origins also informs the ascent of Fitzpatricks who remained in Ireland, since DNA data points to their shared ancestry from the 17th century and earlier.

Colonial American Fitzpatrick Settlers, Part I: Making Sense of One Line also provides a case study that serves to highlight some of the pitfalls of copy and paste genealogical research. Careful attention to records and understanding the difference between proven fact and speculation is the difference between research that 
will bring clarity of connections and that which will bring confusion. Speculative connections can be tested using Y-DNA analysis, providing a way to prove relationships beyond any doubt.

\section{Pre-1649 migrations of Irish to the Americas}

The earliest settlements of Irish in either South or North America cannot be considered enduring. In the Guianas, the Irish Colony at Tauregue (habitacion des Hirlandais) and other Irish-mixed Colonies at Supanapoco and Tocujos, situated in the Amazon River delta, had been destroyed by the Portuguese by 1629 (Williamson, 1923). The significant settlement of numbers of Irish in South America did not eventuate until the 18th century (Murray, 2008).

From 1607 the intent to transport Irish prisoners to the newly established Virginia Colony was clearly apparent and targeted a,

Certaine kinde of swordsmen called Kerne: descended from Horseboyes, Idle persons and unlawfull propigation...if they might be drawne from thence, and imployed to your planting of Virginia: the Countrie should be well freed, and tyme elsewhere Eate them out or amend them. The number of these people in Ireland I suppose will not exceede 7 or 8000 (Lansdowne MSS, 156, f.265).

However, when the advised transportation of Irish to Virginia did begin in 1620, it was not from among Irish rebels, but Anglo-Irish landowners displaced by Chichester's plantation of Wexford (Gwynn, 1932b). Sir Oliver St John's correspondence to the Privy Council is witness that some of the Wexford disaffected were transported (State Papers James I, p.306, 1620) but their numbers were not many since there were noe present meanes of conveying them (Gwynn, 1932b). The arrival of Daniel Gookin in 1621 and the subsequent development in the trade of cattle for tobacco was viewed as a good successe in Virginia. There was the will amongst the Company to accept some Irish into the burgeoning colony; for example, they made an offer to transport out of Ireland 20 or 30 able youthes of 16 or 17 yeares of age to Virginia to be Apprentices for 6 or 7 yeares in the Companies service (Gwynn, 1932b). Before 1649 the number of immigrants with Irish-soundin' surnames was no more than a few hundred (Greer, 1912; O'Brien, 1914a), but far fewer appear to have settled on their land; the estimated number of grantees of land in Virginia between 1628 and 1649 who were Irish is nine (O'Brien, 1914b). However, the failure to settle significant numbers of Irish in early Virginia was due in most part to the Protestant sentiments toward Catholics, not toward the Irish per se.

A similar situation prevailed in Massachusetts, where it was Puritan ideals to the fore. The first substantiated record of an Irish settler is that of the Rev. John Lyford, who landed in Plymouth in 1623. He was dismissed from the colony on account of his Episcopal tendencies, and so the Irish element in Plymouth remained dormant until 1661; Boston, however, was much more accepting (Donovan, 1932).

The eyes of those seeking American ventures had also turned to the northern fringes, but there is no evidence the ill-fated settlement of Newfoundland's Avalon Peninsula by George Calvert, 1st Lord Baltimore, from 16211629 included many Irish (Lyttleton, 2013). Calvert then sought warmer climes, which led him to Virginia, but having converted to Catholicism in 1625, he refused to take the oath of supremacy demanded of him by the Colony, who then blocked the Papist Lord's design of settling among them (Hughes, 1908). Alerted to Jamestown's Irish exiles, now some 70 miles north on the banks of the Potomac River, Calvert sought their settlement out; there he oversaw the building of a chapel by an unrecorded Catholic missionary at a site that became known as White's Neck - so named after the Jesuit, Andrew White (Hughes, 1908).

These were the origins of Calvert's Maryland venture. With the subsequent foundation of the mission at St Mary's (1633-40) by Caecilius Calvert, the 2nd Lord Baltimore, as a refuge for Roman Catholics (Gwynn, 1932a) it might have been anticipated the settlement of many Irish would have resulted. But despite the foundation of the North American Catholic haven relatively few Irish went to Maryland in the early period and were never more than a small fraction of Maryland's colonial population; this due to the preference the English Catholic settlers of Maryland had for English labourers and servants, even if they were Protestant, over the Irish (Purcell, 1934). Those Irish who did manage to find a foothold elsewhere on the mainland in the early years 
were hardworking, hardy and adaptable individuals, such as John Nolin who was among several settlers living in Delaware ca. 1644 (Purcell, 1947) or the first Irish person recorded in Albany (Beverwyck), New York - a certain, Jan Andriessen de lersman Van Dublingh who leased a farm there in 1649. Irishmen in those days, except as Wild Geese, or as slaves deported by the English to their colonies, were not travelers, neither were they colonists or colonisers, and to find one of them in the Dutch town of Beverwyck in the Colony of Rensselaerswyck in New Netherlands in America, so distant from his native shores, among a people alien in race, language, and religion, and withal evidently beloved by the burghers thereof, a landlord and a landowner and a man of substance, is a curious fact (Danaher, 1903).

Along with Boston, the Caribbean must be considered the primary birthplace of the Irish nation in the Americas. The Caribbean Islands were granted to James Hay, 1st Earl of Carlisle, in 1627 (Hughes, 1908), and he well understood the potential of the Americas. By 1612 he had become a director of the Virginia Company (Schreiber, 1984), and he advanced the early English Caribbean interest shown by Sir Thomas Warner, who had settled St Kitts in 1623. While the St Kitts settlement did not result in the establishment of an Irish presence per se, Warner also had the attention of Island Caribs, the French, and hurricane winds (Gwynn, 1929a; Schreiber, 1984), it did set the scene for expansion and the establishment of English colonies across the Caribbean, which would soon draw many Irish to those shores.

The birth-pains of Barbados saw two rival English factions pitted against each other; Carlisle took control via nefarious means in 1629 (Schreiber, 1984) but the year previous Hilton with some Irish accompanying him had passed it by - doubtless it was the idea of armed conflict they did not like. After St Kitts, Hilton and company considered Nevis, the sister isle, the fittest for theire Settlement (Gwynn, 1932b) only for its curtailment by a Spanish ravaging of both islands in 1629 (Schreiber, 1984). Ultimately, central to the settlement of Irish in the Caribbean was an Irish connection, which came by Captain Anthony Briskett, the son of Lodowick Bruschetto of a family of Genoan merchants, who became known as Lodowick Bryskett. Lodowick had settled near Enniscorthy, Co. Wexford ca. 1581 (Gwynn, 1929b) and it was there Anthony came into possession of 120 acres, only to suffer their loss in 1613 under Chichester (Calendar of State Papers, 1877) - so pained, he decided to seek his fortune in the Americas (Gwynn, 1929b). Despite the duress, Warner persisted with St Kitts and Nevis, but after the Spanish visitation of 1629, Montserrat drew his attention; some French and Irish Catholics had fled there, and in 1632 Warner took control (Fiske, 1899).

The following year the Earl of Carlisle appointed Anthony Briskett governor (Gwynn, 1932b), and under his leadership the Irish settlement of the Island began in earnest; as far as Irish were concerned, Montserrat had become the magnet of the Americas. While passing through the West Indian chain of islands in 1634, the missionary Andrew White noted 'some few' Irish Catholics in Barbados 1634 (Hughes, 1908), growth there not helped by conditions so harsh it led to an insurrection of white indentured servants, particularly those Irish (Handler, 1982). In contrast, that same year White observed Montserrat was a noble plantation of Irish Catholique, whome the Virginians would not suffer to live with them because of their religion (Hughes, 1908), and by 1637 Irish settlers in Monserrat, both men and women, were in maximo numero (Gwynn, 1932a).

The Caribbean would become the destination for many Irish and Colonial American Fitzpatrick settlers, Part II: Caribbean origins and $y$-DNA lines will pick up the Caribbean narrative, with a particular focus on the life and times, and descendants of Captain James Fitzpatrick. He is among the first recorded of his surname to set foot in the Americas. The next section of this article, however, explores the reasons for the subsequent waves of migration from Ireland to the Americas, particularly Virginia, since it relates to the case study, William Fitzpatrick.

\section{Irish and Ulster-Scots to the Americas: 1649-1763}

That large numbers of Irish and Ulster-Scots landed on North America's eastern seaboards in the 17th century as indentured servants (however that is interpreted), mostly as those who had decided to seek a new home in the wilderness rather than to endure the accumulated wrongs inflicted upon them (Dunaway, 1944), is well understood by the general North American populace even if the reasons for their migration may not fully be (Keller, 1992). From 1649 the Americas saw several waves of migration from Ireland, which commenced 
following the new departure in the history of English colonial policy that saw many thousands of Irish transported under Cromwell - and no small number landed in New England (Gwynn, 1930).

But to fully understand the origins of Virginia Irish and their reasons for migration, as servants or otherwise, is not trivial. Key to the discussion is a distinction of terms, namely between Irish, Scotch-Irish, and Ulster-Scot. Notwithstanding that the term Scotch-Irish was coined long after the commencement of the migration of settlers from Ireland with prior Scottish origins (The Scotch-Irish, 1908), adopted here are Fallows' (1979, pp.63-68) well-considered definitions. Scotch-Irish is used generally to point to the colonial ancestors of today's Protestant Irish. It is used as a neutral term to indicate those people whom historians have traditionally so labeled. Ulster-Scot will be used narrowly to indicate Presbyterian Scots who left Lowland Scotland, moved to Ireland for some time where they resolutely refused to mix with the native Irish, and then moved again to America where they were humiliated to find themselves considered Irish. The term Irish will be used in a general fashion to describe descendants of all groups from Ireland except those who are probably Ulster-Scots.

Equally as important as these definitions is a background understanding of how and why large numbers of Scots came to be resident in Ireland in the 17th and 18th centuries, i.e., mostly, following the Nine Year's War (1594-1603); by that stage, eastern Cúige Uladh (Ulster) was already subject to some settlement by Scots, but it wasn't until after Tyrone's Rebellion that the colonisation of Cúige Uladh by the Scottish began in earnest. The speculators Hugh Montgomery and James Hamilton each acquired one-third of Con O'Neill's Upper Claneboye territories, with land being transferred to cover the costs incurred by the pair in securing O'Neill's royal pardon. A sufficient number of English and Scottish persons were to be provided by Montgomery and Hamilton to inhabit the estates (Chart, 1942).

It was a sign of events to come; one year after the Flight of the Earls in 1607, a project for the division and plantation of the escheated lands in six several Counties of Ulster; namelie Tirone, Colraine, Donnegall, Fermanagh, Ardmagh and Cavan (Brewer \& Bullen, 1873) was settled by the Crown. Far more than a simple landgrab, the plantation presented a unique, coherent blueprint for an evolving Ulster society ... setting out an entirely new social structure based on a Scottish model (Gillespie, 2007) with Scots in mind since the ruling monarch, James I of England, was also James VI of Scotland (Wormald, 2009).

The plantation of Cúige Uladh was not, at least in the short-term, considered a success (Gillespie, 2007). Nicholas Pynnar's 1618 survey determined a total of just 1,974 families (6,215 bodies with arms, i.e., mean aged 16 to 60) had been planted (Harris, 1770). Hill's (1993) analysis of the 1622 plantation survey provides insights far beyond the stereotype that settlement was by a Scottish Lowland rural population that first fixed the moral and religious tone of the entire province (Hanna, 1902). The Cúige Uladh plantation failed to take root and flourish from 1609 to 1625 except in areas planted by Scots from the Borders-Southwest and this due to a variety of factors including (i) them having a hardier disposition; (ii) their adoption of Irish building and agricultural practices; and (iii) their lack of religious conviction - at least between 1609 and 1625 when most settlers were, in the minds of visiting Presbyterian ministers, openly profane and immoral in their conduct, inasmuch Cúige Uladh could not have been considered Protestant, let alone Presbyterian. In contrast, Lowland Scots and English suffered a culture shock that sent many of them scurrying back home (Hill, 1993).

A 1633 estimate puts the number of those planted in Cúige Uladh as 13,092 (Hanna, 1902), among which several Pátraic surnames are found in records relevant to the early plantation period (for a discussion of Pátraic surname diversity refer Fitzpatrick \& Fitzpatrick, 2020), namely plantation surveys (Hill, 1877), muster rolls (Hunter \& Johnston, 2012) and patent rolls (Patent Roll James, 1967). Gilpatrick is found in An Cabhán (Co. Cavan), An Dún and Tír Eoghain (Co. Tyrone); Kirkpatrick in An Dún, Cúil Raithin (Coleraine), Dún na nGall (Co. Donegal) and Tír Eoghain; Kilpatrick in An Cabhán, An Dún, Cúil Raithin, and Dún na nGall; Patterson in An Dún, Aontroim (Co. Antrim), Ard Mhaca (Co. Armagh), Cúil Raithin, Dún na nGall, Fear Manach (Co. Fermanagh) and Tír Eoghain; and, Patrick in An Dún and Cúil Raithin.

In addition to Scots planters, natives who were tenants on the lands of Scottish or British grantees, were also recorded during the Cúige Uladh surveys, namely: Eóin Mac Giolla Phádraig (Owen McGillpatrick), gent, who is 
associated with several Mac Suibhne (McSwine) and who leased 128 acres in Machaire Mhig Shamhradháin (Magheramagorgan), Dún na nGall ca. 1610; Donnchadh Ó Maol Phádraig (Donnogh O’Mulpatrick) who held two polls in 1628 in Fíoch (Feugh), An Cabhán; Seán Mac Giolla Phádraig (John McGilpatrick) who was associated with Clann Mac Uidhir (Maguire) and held a lease in Tullanaginn, Fear Manach in 1629; and, Aodh Mianáin Mac Giolla Phádraig (Hugh Mynagh McGilpatricke) who let a parcel of land in Ballyloughmagniffe, Tír Eoghain in 1613 (Hill, 1877).

Hence, by 1633 the addition of those with Pátraic surnames from Scotland added to the already complex mix of origins of Pátraic surnames in Cúige Uladh such that trying to unravel those origins, almost 400 years later, in Irish and Ulster-Scots who migrated to North America is an almost impossible task given Pátraic surnames were also increasingly subject to corruption, often to Fitzpatrick, from the middle of the 17 th century (Fitzpatrick \& Fitzpatrick, 2020).

Similarly, the reasons for migration between Ireland and Scotland between 1649 and 1763 are complicated because of wars, famines, and economic events, which served to push and pull migrants between both countries. Nevertheless, a knowledge of the timing of the arrival of Irish and Ulster-Scots in North America can, at least in simple terms, inform some of the likely motivations for migration when aligned with concurrent events in Ireland and Scotland.

By 1649 Ireland and Scotland were reeling from the after-effects of a series of conflicts, namely: the Scottish Bishops' Wars (1638-1640) and Charles I's determination to enforce an episcopal system on Presbyterian Scots (Fissel, 1994); the Irish rebellion against the crown in 1641, which morphed into a war along the lines of religious affiliation, with all its rights and wrongs, that has seen scholars clash over their contrasting opinions (Perceval-Maxwell, 1978); and, the first (1642-1646) and second (1648) English Civil Wars, which intimately involved Presbyterian Scots and the struggle for Scottish independence (Harris, 2015). Amidst those struggles for both political and religious rule came the rise of the New Modelled Army - professional militia with superior arms against which, ultimately, neither Irish nor Scots could resist (Roberts, 2005).

The Crown's 1649-1653 campaign in Ireland was also associated with famine (Crawford, 1989) and plague (Cullen, 1975), and overall resulted in an estimated 15-20\% mortality and a demographic catastrophe (Lenihan, 1997). The subsequent transportation of Irish to the Americas is well known, although some have inflated the number of those transported to the Caribbean up to 50,000 - scholarly estimates are from 5,000 to 20,000 (Donoghue, 2017); indeed, the Irish population of the West Indies could not have exceeded the total white population of 34,000 between 1655 to 1660 (Beckles, 1990).

The political and religious see-sawing in Ireland continued in the decades that followed; the power vacuum after Cromwell's death in 1658 led to the restoration of the Stuart monarchy in 1660 (Edie, 1976) but the outcome of Williamite War (1688-1691) was a Catholic defeat and a Protestant rebound, although Irish Presbyterians also suffered various disabilities (Murtagh, 1993). Rounding off 50 years of total turmoil were the Scottish famines and plagues of the 1690s - the seven ill years (Cullen, 2010). All these factors meant Scots flooded into Ulster during the second half of the 17th century (OhImeyer, 1989), but a similar outflow to North America was on the horizon (Dickson \& Fitzgerald, 2016). Ongoing Episcopalian repression of Presbyterians such as a Test Act introduced in 1704 to prevent the further growth of Popery that also declared Presbyterians incapable of filling the most humble office (Hanna, 1902), a combination of droughts, bad harvests, smallpox, credit crises, rising rents, and weak linen prices from 1726-1729 (Dickson \& Fitzgerald, 2016; Wokeck, 1996), the 1740-41 Irish famine (Crawford, 1989), along with a desire not to regress with respect to economic improvements that had been gained (Keller, 1992) were the main factors driving Irish emigration during the first half of the 18th Century.

The numbers of Irish who migrated to North America up until 1763 are not known with certainty, and even sound estimates vary widely, from approximately 250,000 to 500,000 (Hanna, 1905; Eid, 1986). But, returning to the subject of this article, the numbers of Irish who settled in Virginia can be gauged with more accuracy since Pennsylvania is considered an early distributing center from which Irish moved south because: 
By 1730, the westward movement of population in Pennsylvania had reached the foothills of the Alleghenies, and, being hindered by the mountain barrier from advancing farther in that direction, was deflected southward along the line of least resistance into the valleys of Maryland and Virginia, and into the Piedmont region of the Carolinas (Dunaway, 1931).

The vast majority of Irish emigrants bound for Philadelphia came from one of four Irish ports in either An Cóbh (Cóbh, Co. Cork), Baile Átha Claith (Dublin), Béal Feirste (Belfast) or Doire (Derry), since vessels departed from them frequently. And using sound immigration statistics for the Delaware Valley as a surrogate for Protestant or Catholic affiliation, of the 24,080 Irish who landed in New Castle or Philadelphia between 1729 and 1763 approximately $60 \%$ embarked from ports in Ulster and $40 \%$ from ports in were from the south of Ireland, although between 1729 and 1742 those proportions can be reversed exactly.

Hence, the idea that Scotch-Irish Protestants from Ulster formed the vast majority of Colonial Irish settlers in Virginia is, in all certainty, distorted (Wokeck, 1996) and exaggerated (Eid, 1986) confounded by assumptions that all Irish setters were Scotch-Irish (Dunaway, 1931) and failing to account for the conversion of Catholics to Presbyterians, Anglicans Methodists, Baptists and Quakers in a New World where religious affiliation took a distant second place to building a new life and the spirit of the American revolution (Carroll, 2006). And among those Irish who landed in Pennsylvania and settled in Virginia was William Fitzpatrick; his life and times and descendants are the focus of the remainder of this article.

\section{Colonial American Fitzpatrick Settlers: Copy and Paste Chaos}

One of the prime goals of any DNA surname research project is to make connections between genealogical paper pedigrees and DNA-produced genetic pedigrees. The interest in researching ancestry has grown exponentially in the past ten years. With the availability of online birth, marriage, and death records, anyone can now research their ancestors without having to dig through the information that previously may have been difficult to access. In North America, where the majority of the population descend from immigrants, it is a great quest to connect to one's past through paper trails. As most researchers are well aware, the issue is that you hit what is commonly referred to as a brick wall when the paper trails run out.

A widespread thing happens when the people hit the genealogy brick wall. There is no longer a source available to make a real genealogical connection to an ancestor, and relationships on a tree can become speculative. The speculation is frequently copied by hundreds of other researchers, taken as factual but ignoring that it was based only on guesswork. What can happen on platforms such as ancestry.com (Ancestry) is many trees connect to an ancestor but branching is regularly based on very thin threads, and narratives such as, the trail leads back to Virginia, and the issue with that is most pedigrees that go back to the early colonists all lead back to Virginia or North Carolina.

An example of this is evident in one of the pedigrees this article examines; there is a Virginia settler, William Fitzpatrick, born ca. 1690, who has over 3000 trees connected to him on ancestry via his two sons, His pedigree has been well documented by genealogical researchers, but it is impossible in most cases to tell which lineages are correct. Also, William's line is easy to confuse because there is John Fitzpatrick born ca. 1750, possibly out of Bath County Virginia, and late of Floyd County Kentucky, who has over 1000 trees connected to him, although the historical research done on John's line is very limited. In addition, there is Samuel Fitzpatrick, also born ca. 1750 out of Surrey North Carolina, and late of Maury County, Tennessee; he has less than 150 trees with him as the most distant known ancestor (MDKA), but the opportunity for confusion still exists.

The dominance of William's pedigree at Ancestry, with its richness, detailed narratives, a commonality of forenames (such as John, Thomas, William, and Joseph), his early arrival, and the icing on top - his supposed descent from the Barons of Upper Ossory, a magnet for seekers of famous ancestors (Fitzpatrick \& Fitzpatrick, 2020) - has had the effect of making it easy for genealogists to connect John and Samuel's lines to William's erroneously. However, male descendants of William, John, and Samuel have been proven, by Y-DNA, to be from three different patrilineages. William and Samuel both stem from FGC11134, a significant branch under 
the Celtic haplotype L21, but their shared ancestry is from ca. 1200 AD. And John's branch is under FGC5494, another major branch of L21, but separated from FGC11134 approximately 4000 years ago.

In addition to the three lines mentioned above, there are at least four or five distinct Fitzpatrick lines that originated in 18th Century Virginia and North Carolina. These are stray Fitzpatrick men found in genealogical records, but presently unconnected to a specific Y-DNA line. As discussed in the introduction, it may never be precisely known what drove these Fitzpatricks to cross the Atlantic Ocean, but they became early pioneers and spread throughout Kentucky, Georgia, Tennessee, Missouri, Illinois, Ohio, and eventually expanding into Texas and California. Many acquired their lands by receiving grants from fighting in the American Revolutionary War and the War of 1812. Each of these Fitzpatrick lines has a rich documented history while spreading westward from the original colonies of Virginia and the Carolinas and narratives that will interest anyone who manages to connect with them. Due to the investment made by Fitzpatrick Y-DNA pioneers and the subsequent growth of the Fitzpatrick DNA Project, it may be possible, with a simple Y-DNA test, to connect male descendants of these Fitzpatrick lines to others on the Fitzpatrick haplotree. Such lines include that of the earliest recorded Fitzpatrick in the North American Colonies, Bryan Fitzpatrick of Alligator Creek, North Carolina who would have arrived in the 17th Century or 18th Century:

Bryan Fitzpatrick, conveyed to Thomas Holliway 320 acres on ye Sound of Roanoke and on ye south side of the same on August 1st, 1707 (McMullan, 1982)

Bryan's Will, which was probated in Alligator Creek, North Carolina on 26th March 1709 names three sons Cornelius, Verney, John and Dennis and a daughter Elizabeth (Grimes, 1910); this line is currently being researched by the Fitzpatrick DNA project, and the results of the research will be published in due course.

\section{William Fitzpatrick and Sarah Breckenridge: Complexities and Confusion}

William Fitzpatrick (FT15113), who is the case study of this article, appears in what was then Goochland County, Virginia, where he purchased land; this area eventually became Albemarle County.

William Fitzpatrick from Robert Davis all tracts of land in South Garden among the mountains on branches of Roanoke River November 10, 1738 (Sparacio \& Sparacio, 1988).

There have been suggestions that William was not the first of his line in the colonies. This assumption is found in a reference by A. Evans Wynn, a researcher of Southern American:

Reference to lands left him by his father, Daniel Fitzpatrick, in Hanover County Virginia, by John Fitzpatrick of Pittsy/vania County Virginia (year 1784), indicate that county as an original home of the Fitzpatricks - this line related, no doubt, to the Albemarle and Goochland family. There are no records remaining at Hanover County to prove this (Wynn, 1940).

This is an illustration of a genealogists' use of speculation; the conclusion is based on guesswork only. On the surface, it appears to be common sense, both men lived there, and their name was the same, so they must be related. Speculation is a useful genealogical tool when it is used properly. It should never be used as a statement of fact until it has been thoroughly vetted and sourced. If the source is published, it should be identified as unverified information.

As Wynn stated, there was indeed a Daniel Fitzpatrick in Hanover County, as found in land and Church records:

Thomas Owen purchased 100 acres on the south side of Chickahominy Swamp 2 February 1712, of which he deeded half to Daniel Fitzpatrick 7 February 1714 (Cypalcorp, 2015, p. 183);

In Obedience to the within order, we the Subscribers have met and seen all the within mentioned, and also the Lands of Daniel FitzPatrick and John Watson...1735 (Chamberlayne, 1935). 
How does Wynn make this link between Daniel and the Albemarle County Fitzpatricks? It cannot be made with a wave of the hand; it requires step by step sourced information to build a sound genealogical connection. But at this point, we leave Daniel for future research. This line may be a candidate for John Fitzpatrick's (A1488) progenitor line later found in Floyd County, Kentucky. With a focused approach to further research, such speculation could be turned into fact since there is now the ability within the Fitzpatrick DNA project to look at genealogy through the lens of DNA, use genetic analysis to link stray records, build new branches or completely new trees, and verify the previously unverifiable relationship.

To build an accurate historical narrative surrounding William Fitzpatrick the evidence must be stripped down to factual sources. William purchased land in South Garden, Albemarle County, Virginia, in 1738, which is established from the previously mentioned land deal. This alone tells us nothing more than a William Fitzpatrick was there, in this year and owned land, but it is a vital record and establishes these simple facts. However, we do not know if this is indeed just any William or William (FT15113). After 1738 there are no records to be found relating to William, and we do not have a mention of him until a will, dated 1764 .

Son Thomas I constitute and appoint my sole executor, trustee and manager for my dear wife after my decease, who I doubt not will manage it with all requirements necessary unto my worldly Estate. I will and positively order that all my lawful debts be paid with my funeral charges. Item - all the remainder of my estate I will and bequeath to my well beloved wife Sarah Fitzpatrick during her natural life to be at will and dispose of this named at her pleasure to whom it pleaseth her heart to do. In witness whereof I have hereunto set my hand and seal this 7th Day of December and year of Our Lord one thousand and seven hundred sixty and two. Signed - Will Fitzpatrick Witnesses: Samuel Gay, William Fitzpatrick, John Harris. Albemarle May Court 1764 (Sparacio \& Sparacio, 2000, p, 168).

From the will we learn William's wife was Sarah, and he had a son named Thomas. Hence, the summary of the fact-based knowledge of William Fitzpatrick is quite sparse. How could such basic facts be used to build over 3000 family trees on Ancestry? It is essential to address the copy and paste tool found on many genealogy research platforms that have grown over the last ten years. There is a common expression that if a falsehood is told over and over, it eventually becomes the truth, and the surname of Sarah is an excellent example of this. Anyone that has researched the Fitzpatrick lines of the early settlers is undoubtedly familiar with the couple William Fitzpatrick and Sarah Breckenridge. Where did the surname Breckenridge come from? Could it be based on any documentation or historical reference?

Key here is the incredible piece of genealogical research by Reba Fitzpatrick Lea (1954) entitled, The 'Belfield' Fitzpatricks and 'Elim'; Colemans Their History and Genealogy. With over 20 years of research, it is one of the most detailed and comprehensive written compilations undertaken on the line of William Fitzpatrick and Sarah. A search on Ancestry for Sarah Breckenridge will yield almost 2500 trees linked to her name. And yet her surname is not listed on any document or record; neither is there even a single historical narrative. So, where did the surname attached to her originate on the viral Ancestry Trees? Returning to Lea, in a straightforward paragraph in her book is found the only mention of Sarah with the Brackenridge surname this is more than likely the source of the poison in the well of so many family trees.

Notes concerning Fitzpatrick and Breckenridge Families: William Fitzpatrick, $b$. in Ireland, descendant of Sir John and Lady Ella Fitzpatrick, Earl of Ossory - came to Pennsylvania about 1728 with Irish and Scotch Dissenters. From there into the Valley of Virginia, Augusta County with Alexander Breckenridge. William and his sons had left the church of their fathers and were Presbyterians. It is said Williams' wife was Sarah Jane Breckenridge, a sister of the immigrant Alexander Breckenridge. This has not been definitely established. His sons Thomas and Joseph, and possibly others, were born in Ireland. He and his sons patented land in Goochland County in 1738, 1745, and 1747. This land was on Hardware River and when Albemarle County was cut off from Goochland - 1745 - it became a part of Albemarle (Lea, 1954).

No blame can be affixed to Lea since she makes a very important statement that has been ignored by so many: this has not been definitely established. It is not even clear what of the narrative has not been definitely 
established, but at the very least it has to be the surname of William's wife Sarah being Breckenridge. Also, much of what was stated in the note is purely anecdotal, based on information sent in letters to Lea from others. The reference to Sir John and Lady Ella Fitzpatrick adds significant interest to the narrative until it is realised that John Fitzpatrick, the 1st Earl of Ossory, who married Lady Evelyn (aka Ella) Leveson-Gower, was born in 1719, making it impossible for William to be a direct descendant. Further on in Lea's book, we find the probable source of this information, in a letter attributed to a Mrs. Harris in the Library of the Historical Society of Virginia, who wrote:

Tradition handed down in several branches of the family. Lovey Fitzpatrick, daughter of Thomas Fitzpatrick, who was a son of William (d.1764) who came from Ireland, told descendants of her sister Karen-huppock, who married James Pugh; that her father was descended from Sir John and Lady Ella Fitzpatrick (Lea, 1954).

There was a migration of Irish settlers from Pennsylvania into Virginia ca. 1728, but there is no documentation that William spent time in Pennsylvania, went to Virginia with Alexander Breckenridge, or was Presbyterian. Did Alexander even have a sister, and was she named Sarah? All of the notes that have been accepted and recorded on thousands of Ancestry Trees there is no supporting evidence, and Lea never once claimed the narratives are as factual - they are only notes; Lea even offers a disclaimer to all that read them to treat them as such. That the Breckenridge name is spread throughout the descendants of William Fitzpatricks line is a fact. Using the mother's maiden name in a son's name is not an unusual naming convention among ScotchIrish. However, it was also a widespread naming practice in the early Colonies to use the name of famous solider or friend of the family; Breckenridge is found as a forename and surname in numerous Virginia lines. Hence, there is the possibility that Breckenridge could have been the surname of William's wife; indeed, Lea tried to find a connection but never could.

\section{William Fitzpatrick (FT15113): his descendants to the current day}

Returning to the facts, it is established that William lived in South Garden, Albemarle County, Virginia, and that he had a wife Sarah and a son named Thomas. Significant in the Albemarle County records is that a Thomas Fitzpatrick bought 400 acres from the same vendor (Robert Davis) on the same day (November 10,1738) as William (Sparacio \& Sparacio, 1988). That a kin relationship existed between these two men is clear, but the nature of the connection cannot be established with $100 \%$ certainty. On balance Thomas is most likely the son William mentions in his will dated 1764 because this son Thomas is mentioned in Albemarle County property records from 1750 and 1759, in which he is noted as selling land to William Hamner, who was probably the father of his wife, Elizabeth Henley Hamner, who he married sometime before 1747:

Elizabeth Hamner, a daughter of William Hamner and Mary Elizabeth Henley (and the sixth child listed in her fathers will), married in Albemarle Co., Virginia to Thomas Fitzpatrick (Black \& Ryan, 1981).

Last Will and Testaments (LWTs) are among the most informative records to use in genealogical research, especially before the years of more detailed census taking. The LWT typically mentions wives, all living children, daughters with their married names, and sometimes grandchildren.

\section{Thomas, son of William Fitzpatrick (FT15113)}

The LWT of Thomas, son of William reads as follows:

Thomas Fitzpatrick lived in Albemarle County, Virginia, his LWT dated 2 September 1785, probated December Court of 1797, Albemarle County. Wife Elizabeth Hamner. Issue:

\section{Hamner Fitzpatrick \\ William Fitzpatrick \\ John Fitzpatrick \\ Alexander Fitzpatrick}

(C) Copyright 2020 | All rights reserved | The Fitzpatrick Clan Society

Fitzpatrick, I., Fitzpatrick, M. (2020). Colonial American Fitzpatrick Settlers, Part I: Making Sense of One Line. The Journal of the Fitzpatrick Clan

Society 1, 18-39. doi:10.48151/fitzpatrickclansociety00220, Ver2, 23 May 2021 


\author{
Joseph Fitzpatrick \\ Edward Fitzpatrick \\ Thomas Fitzpatrick \\ Sarah Fitzpatrick \\ Lovey Fitzpatrick \\ Keren-huppock Fitzpatrick (Austin, 2005).
}

William, son of Thomas, married Rebecca Gay the granddaughter of Samuel Gay, who was one of the signatories of the LWT of his grandfather. In turn, William is also mentioned in the LWT of his father-in-law, also named Samuel Gay:

I bequeth to my son by law William Fitzpatrick the money he is due, which is ten pounds; and to his wife, my daughter, the afflicted mans companion and Bostons form foto: these two books I bequeath to my daughter Rebecca Fitzpatrick (Brightwell, 2000).

William Fitzpatrick died aged 62 years in 1809. The children of William and Rebecca were:

\author{
Samuel married Ann Sparks, daughter of David Witt \\ William married Fanny Turner \\ Rebecca married - \\ Alexander \\ Sarah married James Clark and moved to Shelby County \\ John married Jane (Lea, 1954).
}

Samuel Fitzpatrick, born 1771, married Ann Sparks DeWitt on June 18, 1792, in Amherst County, Virginia (Dodd, 2001). He died on July 18, 1825, in Staunton, Augusta County, Virginia, after fathering six children, one of whom is 3rd great-grandfather of a Fitzpatrick DNA Project member, FT15113-A. Samuel's records and pedigrees are excellent and can be readily summarised down to the grandfather of member FT15113-A.

Clough Shelton Fitzpatrick (1815-1903) is mentioned in the will of Samuel Fitzpatrick as his son, and the name Shelton came from a significant family name in Albemarle County, probably after Clough Shelton a Revolutionary War Captain and neighbour to the Fitzpatricks. Clough married Margaret Merritt on November 1, 1835, in Augusta County, Virginia. On May 10, 1903, he died in Virginia, having fathered 18 children with two wives. One of Clough's sons was John William Fitzpatrick (1837-1858); his life was cut short but not before fathering Benjamin Franklin Fitzpatrick, born August 9, 1857, in Harrison County, West Virginia. Benjamin Franklin Fitzpatrick (1857- 1927) and his wife, Prudence Simons, lived their lives in Harrison County, and on July 18, 1888, Henry Frederick Fitzpatrick, the grandfather of member FT15113-A was born. Henry continued the proud tradition of farming in West Virginia.

\title{
Joseph, son of William Fitzpatrick (FT15113)
}

According to Lea (1954), William Fitzpatrick also had a son called Joseph. Joseph has several land purchases documented around the same time and location, some properties adjacent to William and his wife, Sarah. A sixth-great-grandson (FT15113-B) of Joseph Fitzpatrick has traced his line back to him commencing with his great-grandfather Robert Worrill Fitzpatrick (1888 - 1967), who was born in Warren County, Georgia. A commercial photographer, Robert was the son of Henry Harris Fitzpatrick and Martha Jane Worrill.

Henry Harris Fitzpatrick (Plate 1) was born in Morgan County, Georgia, on October 18, 1833. He is listed on the 1860 United States census as a farmer in Warren County, Georgia. He was the father to nine children (Robert being his eighth) and was the son of James Fitzpatrick (1801 - 1847). James Fitzpatrick was born July 5, 1801, in Greene County, Georgia, and he married Sarah Harris on December 28, 1824; the couple's two other children were Mary and William Benjamin Fitzpatrick. 
the Revolutionary War, Benjamin was among the first to settle the lands granted in Georgia:

Benjamin Fitzpatrick, b. Va 1745; d. Buckhead, Morgan Co., Ga., 1821. Served as private, Va. Line; received bounty grant of land in Ga. For his service. Mar. (1) Mary Perkins; in 1784, (2) Sarah Jones. His grave marked by D.A.R.

Children by (1) wife:

Nancy, mar. John High

Constantine (1771-1845), mar. Mary Perkins (1778-1856); 5 children

Frances mar. - Stewart

Children by (2) wife:

Elizabeth, mar. Samuel Clay

William, b. 1786, mar. Nancy Green

Joseph, mar. Nancy Hunter.

Alexander, mar. Nancy Hill.

Susan, mar. (1) Charles Matthews; (2) John Emerson

Bennett, mar. Eliza Shackelford

Mary, mar. Thomas Brown.

James, mar Sarah Harris.

Jesse, mar. (1) Nancy McGowan; (2) Mrs. Phillips (McCall, 1996).

Benjamin and his son William settled the land they claimed along the Oconee River in Green County, Georgia. The river was dammed in 1912 to generate hydropower for nearby textile mills, and the sites of the Fitzpatrick settlements were lost. However, a map dated 1793 (Figure 2) provides the location of Fort Fitzpatrick on the Oconee's upper fork at Fitzpatrick's Ford; Ford and Fort seem to used almost interchangeably in the old records (Hunt, 1973).

Benjamin was the son of Joseph Fitzpatrick and Mary Perrin Woodson; the connection is made very clear here when, in 1761, Benjamin was gifted 200 acres in Albemarle County, Virginia, by his grandfather and namesake Benjamin Woodson, the father of Mary Perrin Woodson:

Benjamin Woodson, of St. Ann's Parish, Albemarle Co. to his grandson Benjamin Fitzpatrick of Co. afsd. deed of gift: 200 acres on head of Cary Creek, in Co. afsd. Part of 400 acres (Valentine, 2007);

October 25, 1770. Benjamin Fitzpatrick to Mary Perkins, dau. of Mary Perkins X, who consents to dau's $m^{\prime}$ ge; sec., Joseph Fitzpatrick (Bentley, 1984);

Children of Joseph Fitzpatrick (1) and Mary Perrin Fitzpatrick

Benjamin, born 1746, married, first, Mary Perkins; second, Sarah Jones (seven sons and five daughters). William, married Miss Phillips (six sons and three daughters) Joseph, married Elizabeth Jones (two sons and three daughters)

Booth, married Miss Brown (two sons)

Rene, married Miss Hartredge. Family not known

Mrs. Joe Heard

Mrs. Robert Wright (Wynn, 1940).

The three brothers Benjamin, William, and Rene were very active on the lands in Greene and Morgan Counties, Georgia; several of their cousins, and eventually their mother Mary Perrin Fitzpatrick, made their homes in the area after the death of Joseph (Hunt, 1973). Joseph Fitzpatrick has several land purchases documented around the same time and location, some properties adjacent to William Fitzpatrick (FT15113) and his wife, Sarah:

January 12, 1746 Joseph Fitzpatrick: Patent for "400 acres in Goochland County on north Fork of Hardware River and bounded by Mildred Merewether's corner." From William Gooch, Lt. Governor and 
Commander-in-Chief at Williamsburg (Wynn, 1940).

Hence, we arrive, having the three men, William, Thomas, and Joseph Fitzpatrick, all located in the same time and place, on land that makes up the North and South Garden between the North Fork and the South Forks of the Hardware River. By all accounts, documented in the official records and anecdotal, the relationship between the three men has William Fitzpatrick (FT15113) and Sarah as the parents of Thomas and Joseph. But $100 \%$ proof is lacking: William, Thomas, and Joseph could be brothers, uncles or cousins, or not related at all. The latter, however, can be verified by Y-DNA analysis.

\section{William Fitzpatrick: making connections via his haplotype}

From the onset of the Fitzpatrick DNA Study (Fitzpatrick, 2005), it was clear there were several Fitzpatrick lines, and they were genetically diverse. One of the more extensive lines was known as the Nine of Clads since it was the ninth line discovered, and it was speculated the line originated in An Cabhán. The line shared an STR marker that was uncommon among L21 men (DYS449=26), and this served as an explicit identifier for those Fitzpatricks who belonged in the Nine of Clads. With the commercialisation of Next Generation Sequencing (NGS) testing came the discovery that the STR-defined line could be more precisely defined as haplotype BY9001, a sub-group of L21...FG11134, which arose ca. 2000 BC. Today, more than 120 men have taken a YDNA test and share ancestry with BY9001, including over 40 Fitzpatricks. The BY9001 haplogroup is made up of lineages that trace to Bréifne (Breffni). This ancient kingdom encompassed much of the present-day counties of An Cabhán and Liatroim (Co.Leitrim) as well as parts of An Longfort (Co.Longford), An Mhí (Co.Meath), Fear Manach and Sligeach (Co.Sligo).

These Fitzpatrick men are found exclusively under the BY9001 sub-haplogroup BY12234, which arose ca. 1050 AD. Hence, this is a line that has carried a Pátraic patronymic since the dawn of surnames (Fitzpatrick \& Fitzpatrick, 2020) and with NGS tests for Fitzpatricks now numbering 12 it is possible to arrange them in their own haplotree along with a timeline of when the tree branching occurred; the haplotree will grow further and branch more with each additional NGS test in the future.

A genetic great-grandson of BY12234 is FT15113 and this mutation is carried by two Fitzpatrick men who both stated their MDKA was as William Fitzpatrick, born ca. 1690, of Albemarle County, Virginia. The pedigrees of both men are well documented, one back to Thomas Fitzpatrick born ca. 1725 and the other to Joseph Fitzpatrick born ca. 1720, both of Albemarle County. Thomas Fitzpatricks is, with a high degree of certainty, the son of the aforementioned William and, based on both descendants sharing FT15113 and his date of birth, Joseph Fitzpatrick was probably his brother.

One of the challenges of working with NGS Y-DNA data relates to the degree of test coverage; a large proportion (approximately 62\%), but not all SNPs on the Y-chromosome are analysed (FamilyTreeDNA, 2014). NGS results did not find any private SNPs for the two descendants of William, which is not unusual for those related within a generation or two, but is unexpected in this case; the explanation is the lack of Y-chromosome coverage. Accordingly, compared with other branches of the BY12234 haplotree, FT15113 SNP gives the impression it arose ca. 1350 AD. The reality is the branch FT15113 belongs to arose ca. 1350 AD, not necessarily the SNP itself. It will require further NGS results to lock down the exact year the split took place between the lines of Joseph and Thomas Fitzpatrick. However, considering the historical records, the fact Thomas is stated to be a son of William, the birth years of the men, and the convergence of the STR data of the other men who also report William as their MDKA, it is entirely reasonable to conclude that the two men tested (FT15113-A and FT15113-B) share common ancestry with William Fitzpatrick born ca. 1690 (refer . Figure 3)

In addition to the two descendants of Thomas and Joseph, other closely STR-matched men also share common ancestry within the last 250 to 350 years, and some of them trace their lineages to Virginia in the 1700 s. Figure 4 presents a Time to Most Recent Common Ancestor (TMRCA) chart for haplogroup BY12234; this group comprises Fitzpatricks and genetic cousins with Scots-associated surnames and highlights the cluster of Virginia related Fitzpatricks.

(C) Copyright 2020 | All rights reserved | The Fitzpatrick Clan Society

Fitzpatrick, I., Fitzpatrick, M. (2020). Colonial American Fitzpatrick Settlers, Part I: Making Sense of One Line. The Journal of the Fitzpatrick Clan Society 1, 18-39. doi:10.48151/fitzpatrickclansociety00220, Ver2, 23 May 2021 
With the combined DNA and genealogical information at hand it is now possible to find other descendants of William Fitzpatrick (FT15113). For example, several American Fitzpatrick family trees stop at a brick wall in the early 1800s with a Thomas Richardson Fitzpatrick born ca 1815 in Madison County, Georgia. A descendant of Thomas Richardson Fitzpatrick determined to see if a Y-DNA test could break through the brick wall, and a 37 marker DNA test was taken. Both the resultant STR signature and TMRCA calculations confirmed Thomas Richardson Fitzpatrick descended from William Fitzpatrick (FT15113).

Can any more be learned of William's Irish origins? A speculator might take Rea's (1954) account that William and his sons were Presbyterians on face-value and doubtless also consider his forename a sure sign he was Scotch-Irish. But Lea (1954) also states William and his sons had left the church of their fathers. This, and the fact that William arrived on North American shores ca. 1728, when Catholics migrants outnumbered Protestants by three to two, points to Irish roots. The complexity of William's close Y-DNA matches is such that Scotch-Irish also feature with a shared ancestry before ca. 1350 AD. Does this point to a pre-1350 AD movement, from Ireland to Scotland, of members of a Clann who bore a Pátraic surname, only for some of their descendants to return to Ireland some 300 or so years later?

This fascinating aspect of the FGC11134...BY12234 line of Fitzpatricks will be explored in future articles. For the time being, concerning early American Fitzpatrick research, this article teaches us overall to take nothing for granted, question all prior assumptions, and utilise $Y$-DNA to break down brick walls. 


\section{References}

Austin, H. (2005). The Georgia Frontier. Volume II: Revolutionary War Families to the Mid-1800's, Volume II: Baltimore, Maryland Clearfield.

Beckles, H. (1990). A "riotous and unruly lot": Irish Indentured Servants and Freemen in the English West Indies, 16441713. The William and Mary Quarterly, 47, 503-522.

Bentley, B. (1920). Tennessee Scotch Irish ancestry. Tennessee Historical Magazine, 5, 201-211.

Bentley, E. (1984). Virginia Marriage Records: From the Virginia Magazine of History and Biography. William and Mary College Quarterly, and Tyler's Quarterly. Baltimore, MD: Genealogy Publishing Co., Inc.

Black, G., Ryan, M. (1981). Hamner heritage: Beginning without end. Bear Creek, Ala: Cesco Press.

Brewer, J. \& Bullen, W. (Eds.) (1873). Calendar of the Carew Manuscripts preserved in the Archiepiscopal Library at Lambeth, Vol. V.

Brightwell, L. (2000). Gay or Gayre Family History. Lulu Press.

Bullen, W., Brewer, J. Calendar of the Carew manuscripts: preserved in the archi-episcopal library at Lambeth London: Longmans, Green, Reader, \& Dyer.

Calendar of State Papers (1877). Ireland, 1611-1614. Edited by C. Russell and Prendergast, J. London: Longman and Co.

Carlson, L. (1942). A History of the Presbyterian Party from Pride's Purge to the Dissolution of the Long Parliament. Church History,11(2), 83-122.

Carroll, M. (2006). How the Irish Became Protestant in America. Religion and American Culture: A Journal of Interpretation, 16, 25-54.

Chamberlayne, C. G. (1935). The Vestry Book of St. Paul's Parish, Hanover County, Virginia, 1706-1786. Clearfield Co.

Chart, D. (1942). The Break-Up of the Estate of Con O'Neill, Castlereagh, County Down, temp. James I. Proceedings of the Royal Irish Academy. Section C: Archaeology, Celtic Studies, History, Linguistics, Literature, 48, 119-151.

Crawford, E. (1989). Famine: The Irish experience, 900-1900: subsistence crises and famines in Ireland. Edinburgh: J. Donald.

Cullen, K. (2010). Famine in Scotland - the 'Ill Years' of the 1690s. Edinburgh: Edinburgh University Press.

Cullen, L. (1975) Population trends in seventeenth-century Ireland. Economic and Social Research Institute, Economic and Social Review, 6, 149-165.

Cypalcorp (2015). Henrico County, Virginia Court Order Book, 1710-1714. Iberian Publishing Co., pp.226.

Danaher, F. M. (1903). Early Irish in old Albany, N.Y: With special mention of Jan Andriessen, 'De lersman Van Dublingh'. Boston, Massachusetts: American-Irish Historical Society.

Dickson, R., Fitzgerald, P. (2016). Ulster emigration to colonial America, 1718-1775. Belfast: Ulster Historical Foundation.

Dodd, J. (2001). Virginia marriages, early to 1800. North Salt Lake, Utah: Heritage Quest.

Donoghue, J. (2017). The Curse of Cromwell: Revisiting the Irish slavery debate. History Ireland, 25, 24-28.

Donovan, G. (1932). The pre-revolutionary Irish in Massachusetts, 1620-1775. Menasha, Wisconsin: George Banta Pub. Co. 
Dunaway, W. (1931). Pennsylvania as an Early Distributing Center of Population. The Pennsylvania Magazine of History and Biography, 55, 134-169.

Dunaway, W. Fuller. (1944). The Scotch-Irish of colonial Pennsylvania. Chapel Hill: University of North Carolina Press.

Edie, C. (1976). The Popular Idea of Monarchy on the Eve of the Stuart Restoration. Huntington Library Quarterly, 39, 343373.

Eid, L. (1986). Irish, Scotch and Scotch-Irish, A Reconsideration. American Presbyterians, 64, 211-225.

Fallows, M. (1979). Irish Americans: identity and assimilation. Prentice-Hall, Englewood Cliffs, N.J.

FamilyTreeDNA, 2014. BigY White Paper. https://learn.familytreedna.com/wpcontent/uploads/2014/08/BIG Y WhitePager.pdf (accessed on 1 July 2020).

FamilyTreeDNA, 2020. Fitzpatrick. Fitzpatrick DNA Project. https://www.familytreedna.com/groups/fitzpatrick (accessed on 1 July 2020).

Fiske, A. (1899). The West Indies: a history of the islands of the West Indian archipelago, together with an account of their physical characteristics, natural resources, and present condition. New York: G. P. Putnam's Sons.

Fissel, M. (1994). The bishops' wars: Charles I's campaigns against Scotland, 1638-1640. Cambridge: Cambridge University Press.

Fitzpatrick, C. 2005. Fitzpatrick DNA Study:

https://web.archive.org/web/20070524204954/http:/www.genealogy.com:80/genealogy/users/f/i/t/Colleen-FitzpatrickCA/index.html (accessed on 1 July 2020).

Fitzpatrick, E.; Fitzpatrick, M. When Everything Changes: Using Critical Family History to Deconstruct Keesing and Fitzpatrick Surnames. Genealogy 2020, 4, 25.

George III, 1763. Proclamation of 7 October 1763. Great Britain, Sovereign (1760-1820: George III). Constitutional and Organic Papers. S131006. South Carolina Department of Archives and History, Columbia, South Carolina.

Gillespie, R. (2007). After the Flight: The Plantation of Ulster. History Ireland, 15, 40-45.

Glatfelter, C. (1946). Pennsylvania Antecedents of Scotch-Irish Presidents. The Historian, 8, 131-139.

Greer, G. (1912). Early Virginia immigrants. Richmond, Va.: W.C. Hill Printing Co.

Grenham, J. (2019). Tracing your Irish ancestors. Dublin: Gill Books.

Grimes, J. (1910). Abstracts of North Carolina Wills. Raleigh, NC, USA: North Caroline Department of State, 1910. Harper, A. B. (1955). Families Lines.

Gwynn, A. (1929a). Early Irish Emigration to the West Indies (1612-1643). Studies: An Irish Quarterly Review, 18, $377-393$.

Gwynn, A. (1929b). Early Irish Emigration to the West Indies: Part II. Studies: An Irish Quarterly Review, 18(72), 648-663.

Gwynn, A. (1930). Cromwell's Policy of Transportation. Studies: An Irish Quarterly Review, 19, 607-623.

Gwynn, A. (1932a). The First Irish Priests in the New World. Studies: An Irish Quarterly Review, 21(82), 213-228.

Gwynn, A. (1932b). Documents relating to the Irish in the West Indies. Analecta Hibernica, 4, 139-286.

Handler, J. (1982). Slave revolts and conspiracies in seventeenth-century Barbados. Nieuwe West-Indische Gids/New West Indian Guide, 56, 5-42. 
Hanna, C. (1902). The Scotch-Irish: or, The Scot in North Britain, north Ireland, and North America. New York: G.P. Putnam's Sons.

Harris, T. (2015). Revisiting the Causes of the English Civil War. Huntington Library Quarterly, 78, 615-635.

Harris, W. (Ed.) (1770). Hibernica. Dublin: Milliken.

Hill, G. (1877). An historical account of the plantation in Ulster at the commencement of the seventeenth century, 16081620. Belfast: M'Caw, Stevenson \& Orr.

Hill, J. (1993). The Origins of the Scottish Plantations in Ulster to 1625: A Reinterpretation. Journal of British Studies, 32(1), 24-43.

Horning, A. (2002). Myth, Migration, and Material Culture: Archaeology and the Ulster Influence on Appalachia. Historical Archaeology, 36(4), 129-149.

Hughes, T. (1908). History of the Society of Jesus in North America: colonial and federal. London: Longmans Green \& Co.

Hunt, C. (1973). Ocenee Temporary Boundary. Laboratory of Archeology, Department of Anthropology, University of Georgia.

Hunter, R, Johnston, J. (2012). 'Men and arms': The Ulster settlers, c. 1630. Belfast: Ulster Historical Foundation.

Keller, K. (1992). The Origins of Ulster Scots Emigration to America: A Survey of Recent Research. American Presbyterians,70(2), 71-80.

Lansdowne MSS, 156, f.265, British Museum, London, England.

Lea, R. Fitzpatrick. (1954). The 'Belfield' Fitzpatricks and 'Elim' Colemans: their history and genealogy. Lynchburg, Va.: Brown-Morrison Co.

Library of Congress, 2020. http://www.americaslibrary.gov/jb/colonial/jb colonial subj.html (accessed on 1 July 2020).

Lenihan, P. (1997). War and population, 1649-52. Irish economic and social history, 24, 1-21.

Ligon, R. (1657). A True and Exact History of Barbados. Indianapolis: Hackett Publishing Co. Ltd.

Lyttleton, J. (2013). The Lords Baltimore in Ireland and North America: The beginning of an Atlantic world. Archaeology Ireland, 27, 19-22.

McCall, E. (1996). Roster of Revolutionary Soldiers in Georgia, volume I. Baltimore: Genealogical Pub. Co.

McMullan, P. (1982). History of Development of the Albemarle-Pamlico Region with Emphasis on Dare, Hyde and Tyrell Counties. Willmington North Carolina: US Army Corps of Engineers.

Mervine, W. (1912). The Scotch Settlers in Raphoe, County Donegal, Ireland. A Contribution to Pennsylvania Genealogy. The Pennsylvania Magazine of History and Biography, 36, 257-272.

Moody, T. (1946). Irish and Scotch-Irish in Eighteenth-Century America. Studies: An Irish Quarterly Review, 35(137), 8590.

Murray, E. (2008). Secret Diasporas: The Irish in Latin America and the Caribbean. History Ireland, 16, 15-19.

Murtagh, H. (1993). The Williamite War 1689-91. History Ireland,1, 39-42.

O’Brien, M. (1914a). Early immigrants to Virginia (1623-1666) collected by George Cabell Greer, Clerk, Virginia State Land Office, from the records of the Land Office, in Richmond. The Journal of the American Irish Historical Society, 13, $209-213$. 
O'Brien, M. (1914b). Grantees of lands in the Colony and State of Virginia - copied from the County records of Virginia. The Journal of the American Irish Historical Society, 13, 214-219.

Ohlmeyer, J. (1999). Driving a Wedge within Gaeldom: Ireland \& Scotland in the Seventeenth Century. History Ireland, 7, 27-31.

Paterson, T. (1970). An Unpublished Early 17th Century Census of the Men and Arms on the Estates of the English and Scotch Settlers in Co. Armagh. Seanchas Ardmhacha: Journal of the Armagh Diocesan Historical Society, 5(2), $401-417$.

Perceval-Maxwell, M. (1978). The Ulster Rising of 1641, and the Depositions. Irish Historical Studies, 21(82), $144-167$.

Purcell, R. (1934). Irish Colonists in Colonial Maryland. Studies: An Irish Quarterly Review, 23, 279-294.

Purcell, R. (1947). Irish settlers in early Delaware. Pennsylvania History: A Journal of Mid-Atlantic Studies, 14, 94-107.

Reily, J. (1905). The Irish and Catholics In the Virginia Valley. The American Catholic Historical Researches, 1, new series, 14-16.

Roberts, K. (2005). Cromwell's War Machine: The New Model Army, 1645-1660. Barnsley: Pen \& Sword Military.

Schaeffer, A. (1943). Early Scotch-Irish settlements in Pennsylvania. Pennsylvania History: A Journal of Mid-Atlantic Studies, 10, 141-147.

Schreiber, R. (1984). The First Carlisle Sir James Hay, First Earl of Carlisle as Courtier, Diplomat and Entrepreneur, 15801636.

Smith, J., 1580-1631. (1907). The generall historie of Virginia, New England \& the Summer isles, together with the true travels, adventures and observations, and a sea grammar. Glasgow: J. MacLehose and sons.

Sparacio, R., Sparacio, S. (1988). Deed abstracts of Albemarle County, Virginia. McLean, Virginia: Antient Press.

Sparacio R., Sparacio S. (2000). Virginia County Court Records, Albemarle County, Virginia, Wills (Book 2) 1752-1764. The Antient Press, McLean, VA.

Stone, F. (1890). First Congress of the Scotch-Irish in America. The Pennsylvania Magazine of History and Biography, 14, 68-71.

Sweeny, R. (2006). What difference does a mode make? A comparison of two seventeenth-century colonies: Canada and Newfoundland. The William and Mary Quarterly, 63, third series, 281-304.

The Scotch-Irish. Early Irish Settlers called themselves Irish and nothing more. (1908). The American Catholic Historical Researches, 4, new series, 40-44.

Valentine, E. (2007). The Edward Pleasants Valentine papers: Abstracts of records in the local and general archives of Virginia relating to the families of Allen, Bacon, Ballard, Batcheldar, Bloute, Brassieur (Brashear), Cary, Crenshaw, Dabney, Exum, Ferris, Fontaine, Gray, Hardy, Isham (Henrico County), Jordan, Langston, Lyddall, Mann, Mosby, Palmer, Pasteur, Pleasants, Povall, Randolph, Satterwhite, Scott, Smith (the family for Francis Smith of Hanover County), Valentine, Waddy, Watts, Winston, Womack, Woodson. West Jordan, Utah: Stemmons Pub.

Virginia Company of London., Kingsbury, S. M. (Susan Myra). (19061935). The records of the Virginia company of London: the court book, from the manuscript in the Library of Congress. Washington, D. C.: Government Printing Office. Williamson, J. (1923). English colonies in Guiana and on the Amazon: 1604-1668. Oxford: Clarendon Press.

Wokeck, M. (1996). Irish Immigration to the Delaware Valley before the American Revolution. Proceedings of the Royal Irish Academy. Section C: Archaeology, Celtic Studies, History, Linguistics, Literature, 96C, 103-135.

Wormald, J. (2009). A very British problem: The Stuart Crown and the Plantation of Ulster. History Ireland, 17, 20-23.

Wynn, A. (1940). Southern Lineages - Records of Thirteen Families. The Author. 
Figure 1: Fitzpatrick Bréifne Clan Tree (BY12234)

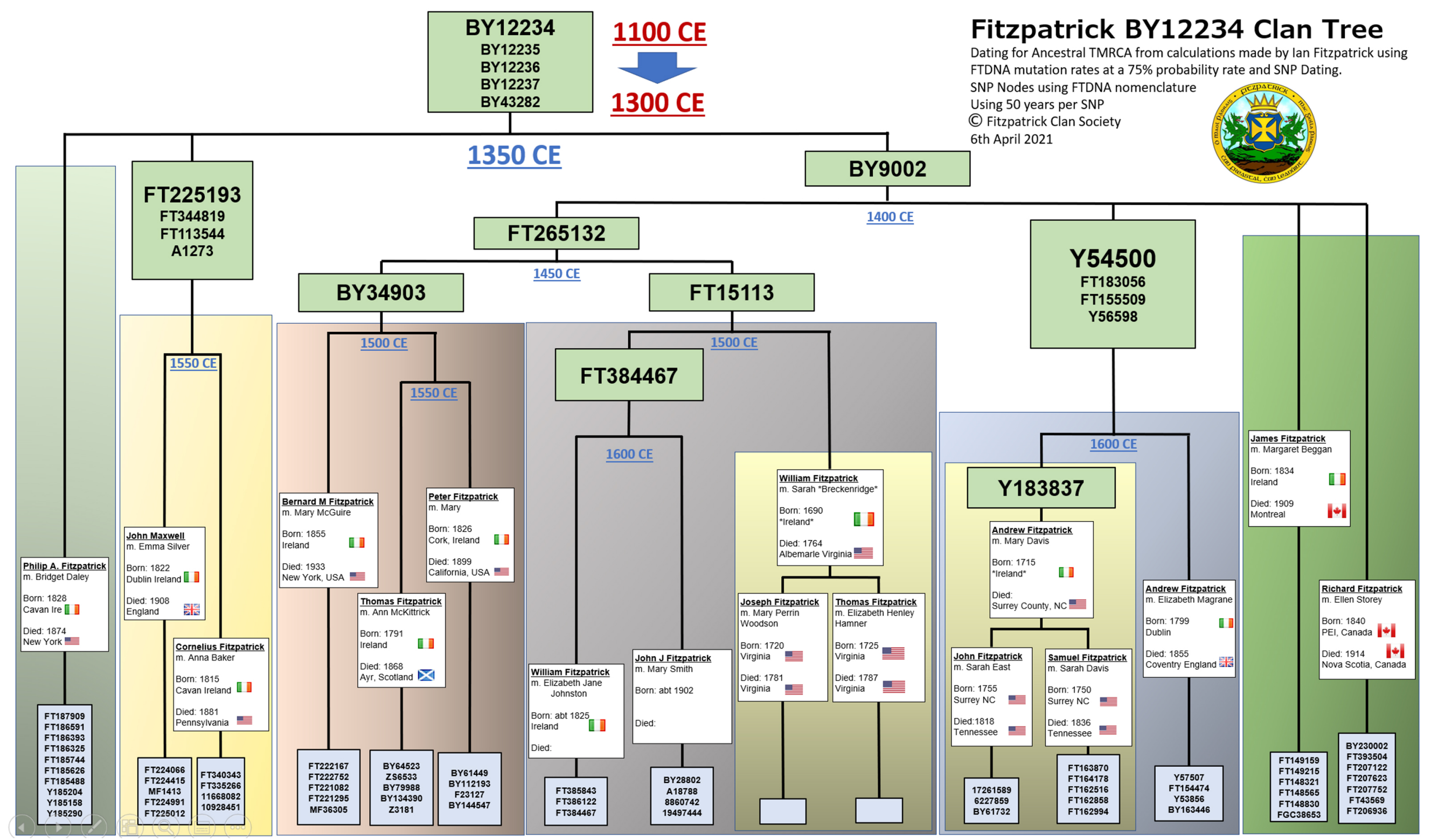

(C) Copyright 2020 | All rights reserved | The Fitzpatrick Clan Society

Fitzpatrick, l., Fitzpatrick, M. (2020). Colonial American Fitzpatrick Settlers, Part I: Making Sense of One Line. The Journal of the Fitzpatrick Clan

Society 1, 18-39. doi:10.48151/fitzpatrickclansociety00220, Ver2, 23 May 2021 
Plate 1: Henry Harris Fitzpatrick, 1833-1894 (used with permission from Meg Monthan)

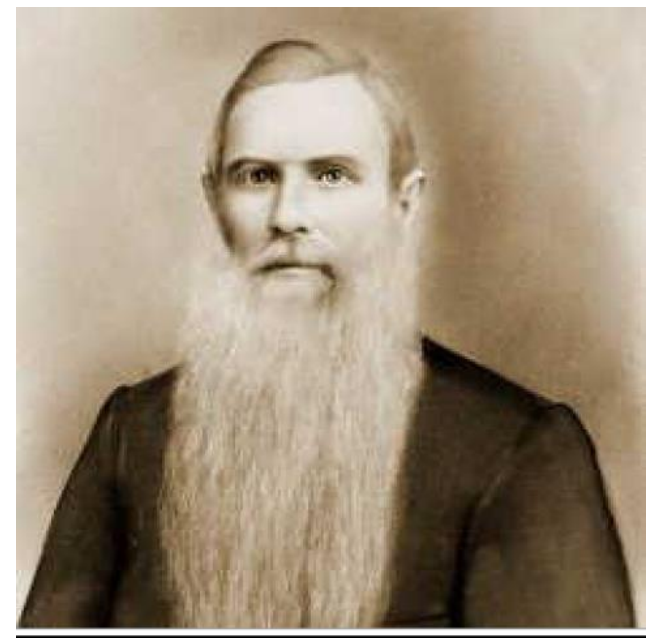

Figure 2: Fort Fitzpatrick on the Oconee River's Upper Fork (Hunt, 1973)

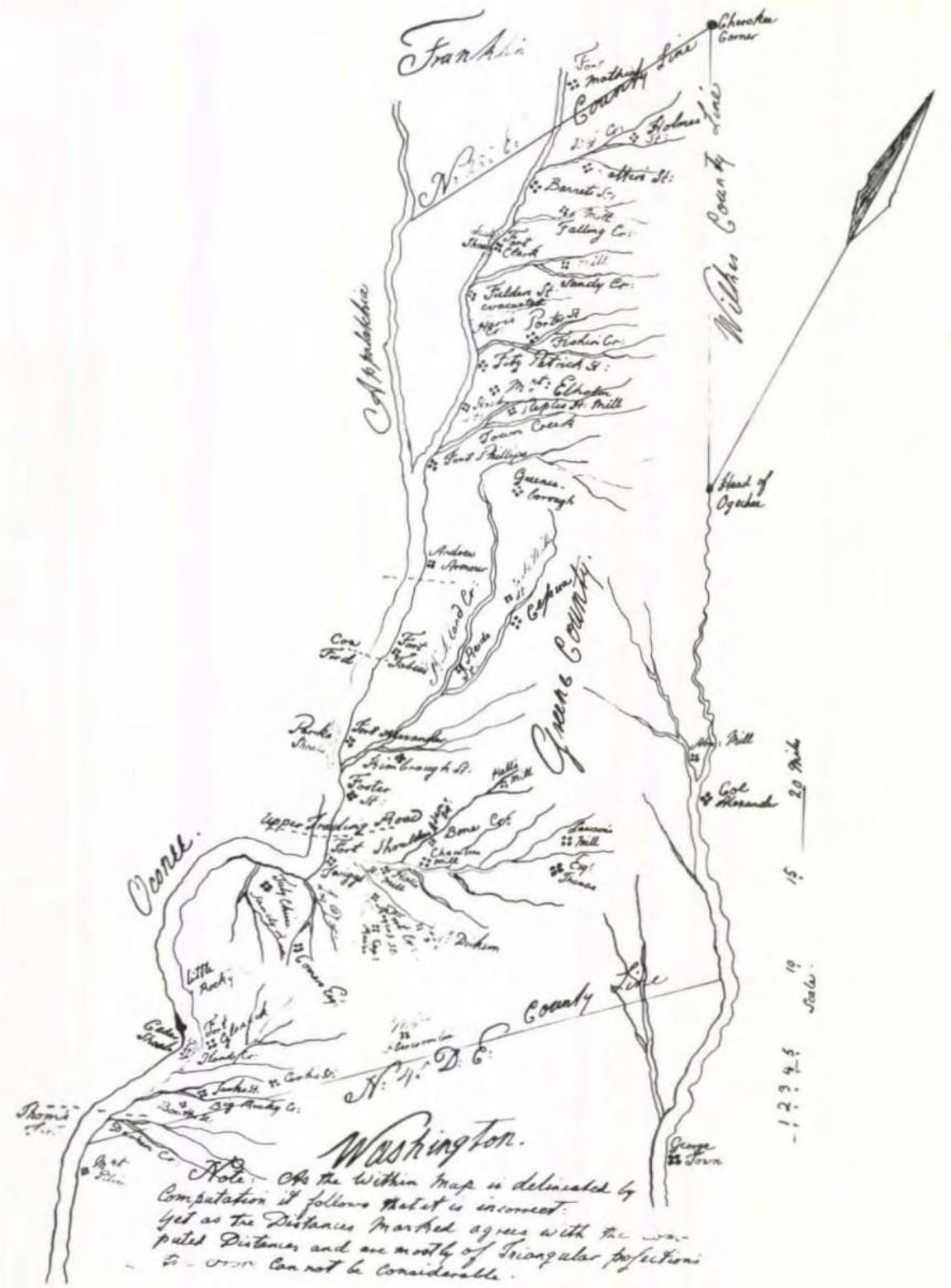


Figure 3: Pedigree of William Fitzpatrick (FT15113)

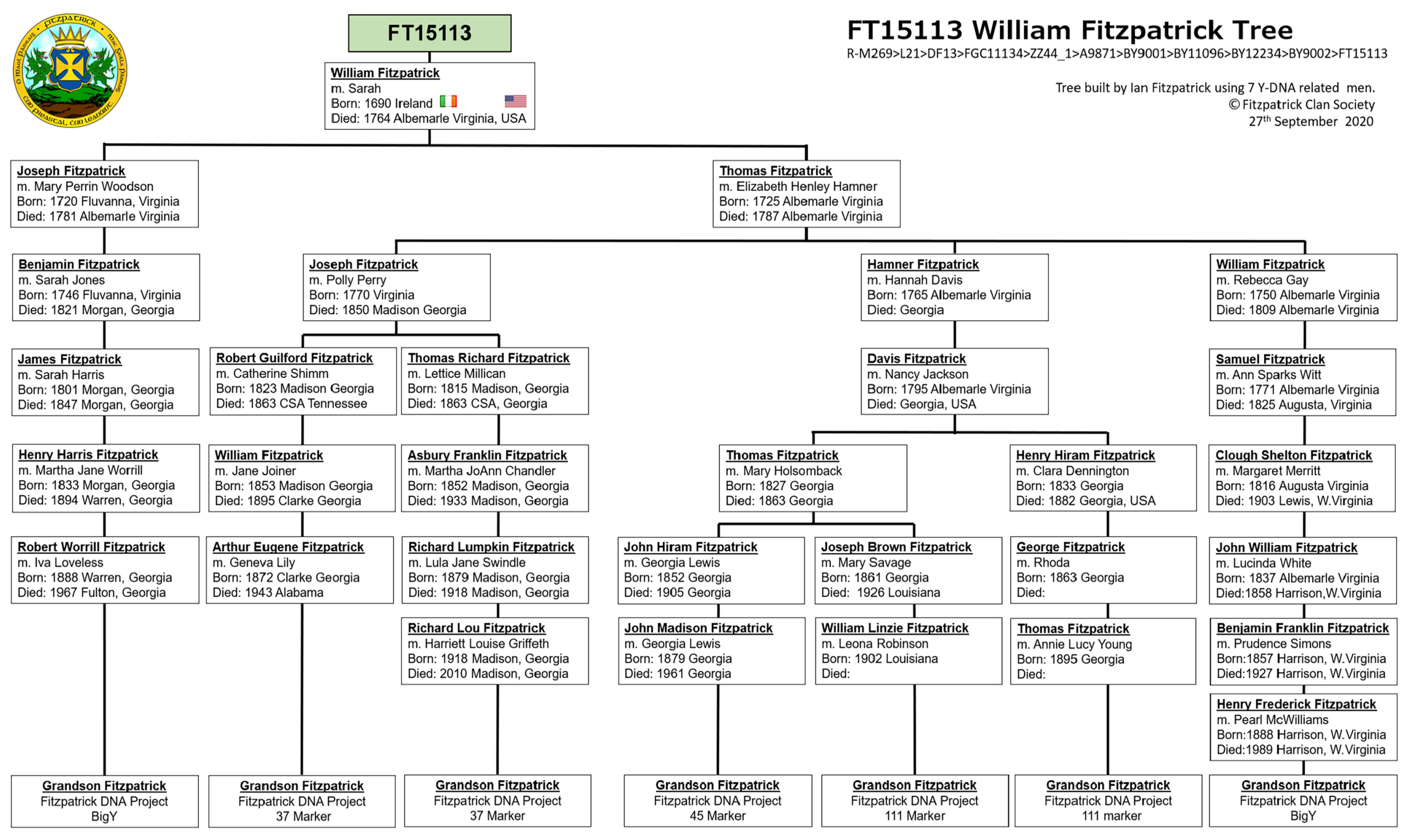

(C) Copyright 2020 | All rights reserved | The Fitzpatrick Clan Society

Fitzpatrick, I., Fitzpatrick, M. (2020). Colonial American Fitzpatrick Settlers, Part I: Making Sense of One Line. The Journal of the Fitzpatrick Clan

Society 1, 18-39. doi:10.48151/fitzpatrickclansociety00220, Ver2, 23 May 2021 
Figure 4: TMRCA Chart for FT15113 Fitzpatrick

Time to Most Recent Common Ancestor (Years)

\begin{tabular}{|c|c|c|c|c|c|c|c|c|c|c|c|c|c|c|c|c|c|c|c|c|c|c|c|c|c|c|c|c|c|c|c|c|c|c|c|c|c|c|c|c|c|c|c|c|c|c|}
\hline ID & & 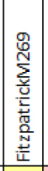 & 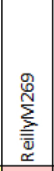 & 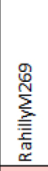 & 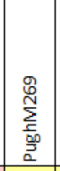 & 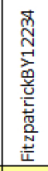 & 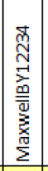 & 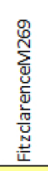 & 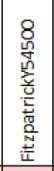 & 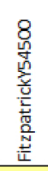 & 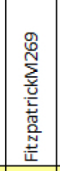 & 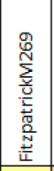 & 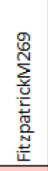 & 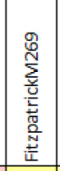 & 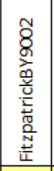 & 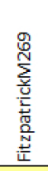 & 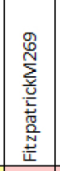 & 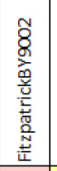 & 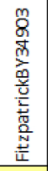 & 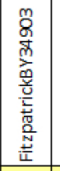 & 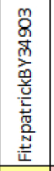 & 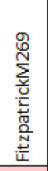 & 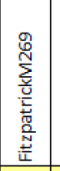 & 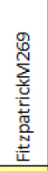 & 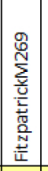 & 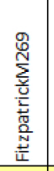 & 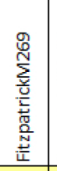 & 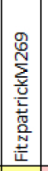 & 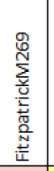 & 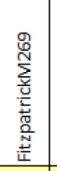 & & 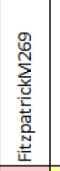 & 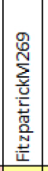 & 童 & 98 & & & & 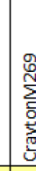 & & & 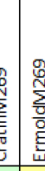 & & & & \\
\hline nodal & & 450 & \begin{tabular}{|l|l|}
660 \\
920
\end{tabular} & \begin{tabular}{|l|l|}
660 \\
922 \\
\end{tabular} & \begin{tabular}{|l|}
330 \\
620
\end{tabular} & 510 & 390 & 330 & & 510 & \begin{tabular}{|l|}
450 \\
690
\end{tabular} & & \begin{tabular}{|l|l|}
660 \\
93
\end{tabular} & \begin{tabular}{|l|}
510 \\
630
\end{tabular} & \begin{tabular}{|l|l|}
450 \\
\end{tabular} & & 690 & & & \begin{tabular}{|l|}
570 \\
702
\end{tabular} & \begin{tabular}{|l|l|}
510 \\
\end{tabular} & & 390 & 510 & 420 & 450 & & & 630 & & & & & 42 & & & 600 & \begin{tabular}{|l|l|}
450 \\
720
\end{tabular} & & & & 33 & & & & \\
\hline patrickM269 & & $\left|\begin{array}{|l}46 \\
930\end{array}\right|$ & \begin{tabular}{|l|}
930 \\
35 \\
\end{tabular} & \begin{tabular}{|l|}
930 \\
240
\end{tabular} & \begin{tabular}{|l|}
630 \\
540
\end{tabular} & \begin{tabular}{|l|l|}
660 \\
\end{tabular} & $\left|\begin{array}{|c|}\mid 900 \\
780\end{array}\right|$ & $\begin{array}{l}780 \\
930\end{array}$ & & $\begin{array}{l}9900 \\
1200\end{array}$ & \begin{tabular}{|l|}
690 \\
930
\end{tabular} & 900 & $\begin{array}{l}930 \\
7800\end{array}$ & \begin{tabular}{|l|}
630 \\
900
\end{tabular} & 1050 & $\begin{array}{l}780 \\
930\end{array}$ & $\begin{array}{l}900 \\
1200\end{array}$ & 1200 & 30 & \begin{tabular}{|l}
780 \\
930
\end{tabular} & 660 & 30 & \begin{tabular}{|l|}
6990 \\
7800
\end{tabular} & $\begin{array}{l}900 \\
930\end{array}$ & 80 & $\frac{990}{1050}$ & \begin{tabular}{l|}
630 \\
750
\end{tabular} & & $\begin{array}{r}\frac{750}{1050} \\
\end{array}$ & $\frac{780}{930}$ & & \begin{tabular}{|c|c|}
900 & 5 \\
1050 & 7
\end{tabular} & & 750 & 750 & 660 & $\begin{array}{l}660 \\
540\end{array}$ & \begin{tabular}{|l|}
780 \\
930
\end{tabular} & 4 & $\frac{690}{544}$ & & \begin{tabular}{l|l}
0 & 45 \\
0
\end{tabular} & 66 & & & \\
\hline $\begin{array}{l}\text { elllyM2 } \\
\text { hillyM }\end{array}$ & & 930 & 240 & 35 & 540 & 660 & 780 & 930 & 200 & 1200 & \begin{tabular}{|l|}
930 \\
\end{tabular} & 900 & & \begin{tabular}{|l|}
900 \\
\end{tabular} & 105 & & 1200 & & 780 & 930 & 660 & & 780 & 930 & & 1050 & 750 & & 1050 & 930 & & $\begin{array}{l}1050 \\
1050\end{array}$ & & 750 & 50 & 000 & $\begin{array}{l}540 \\
540\end{array}$ & $\frac{30}{30}$ & 54 & $54 \mathrm{C}$ & & $\begin{array}{l}50 \\
50 \\
50\end{array}$ & $\frac{660}{666}$ & 66 & $\frac{0.66}{0.66}$ & $\frac{0.06}{0.6}$ \\
\hline n & & 630 & 540 & 540 & 65 & & & 450 & & 630 & & & & 720 & & & 900 & & & 540 & & & 390 & 540 & & 540 & & & 870 & & & & & & & & & & & & & 33 & & & & \\
\hline tzpatrickB & & 690 & 60 & & 30 & 9 & & 630 & 60 & 10 & 90 & 50 & & 750 & 310 & 80 & 900 & 840 & 40 & 840 & \begin{tabular}{|l|}
690 \\
\end{tabular} & 80 & 630 & 630 & & 540 & 630 & & 0 & 630 & & & & & & & & & & & & & & & & \\
\hline axwellB & & 690 & 780 & 780 & 450 & 0 & & 570 & 810 & 750 & 65 & 0 & & \begin{tabular}{|l|}
630 \\
\end{tabular} & 690 & & 900 & 84 & & 690 & & 30 & 450 & 630 & & 630 & 63 & & 750 & 630 & 780 & 900 & & & & & & & & & & & & & & \\
\hline claren & & & 930 & 930 & 450 & & 570 & 109 & 900 & 630 & & & & 900 & & & & & & 690 & & & 570 & & & & & & & & & 900 & & 75 & & 780 & 78 & & & & & & 450 & & & \\
\hline tzpatrick & & 900 & 1200 & 1200 & \begin{tabular}{|l|}
720 \\
\end{tabular} & & 810 & 840 & 09 & 690 & \begin{tabular}{|l|}
900 \\
\end{tabular} & 900 & 1050 & \begin{tabular}{|l|}
750 \\
\end{tabular} & \begin{tabular}{|l|}
900 \\
\end{tabular} & 1050 & & \begin{tabular}{|l|}
900 \\
\end{tabular} & 00 & \begin{tabular}{|l|l|}
840 \\
\end{tabular} & 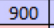 & 1050 & 690 & & & 900 & & & 1020 & 900 & 1 & \begin{tabular}{|l|l}
1020 \\
\end{tabular} & & 75 & & 930 & & 960 & & & & 81 & 811 & 59 & & \\
\hline tzpatrick & & 900 & 1200 & 1200 & \begin{tabular}{|l|l|}
630 \\
\end{tabular} & & 750 & 630 & 90 & 109 & \begin{tabular}{|l|}
690 \\
\end{tabular} & 00 & 1050 & \begin{tabular}{|l|}
750 \\
\end{tabular} & & 1050 & 1020 & 750 & 10 & \begin{tabular}{|l|l|}
9000 \\
\end{tabular} & 40 & 1050 & 750 & & 9 & 630 & 900 & & 102 & 810 & \begin{tabular}{|l|l|}
1050 \\
\end{tabular} & 900 & 750 & 750 & 30 & 930 & 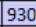 & 810 & & & & 63 & 620 & 51 & 078 & 6 \\
\hline tzpe & & 690 & 930 & 930 & 30 & & 90 & 780 & 0 & 590 & 46 & 10 & & 510 & & 540 & 690 & 90 & 80 & & 80 & 930 & 690 & & & 00 & & & 800 & & 80 & & & & & & & & & & & 45 & & 45 & 054 & a \\
\hline & & 630 & & & & & & & & & & & & & & & & & & & & & 750 & & & & & & & & & & & & & & & & & & & & & & & \\
\hline tzpat & & 930 & 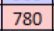 & & 780 & 0 & 30 & 1050 & 1050 & 1050 & & 50 & & \begin{tabular}{|l|}
480 \\
\end{tabular} & & & 660 & & & & & & 780 & 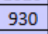 & & 1050 & 00 & & & 9 & 930 & 900 & 900 & & & & & & & & & & 0000 & & & \\
\hline tratsic & & \begin{tabular}{|l|l|}
630 \\
\end{tabular} & & & & & 630 & 900 & 750 & 750 & & & & \begin{tabular}{|l|l}
43 \\
\end{tabular} & & & 510 & & & & & 900 & 750 & & & & & & 900 & & , & 750 & 630 & 63 & 60 & 600 & 6 & & & & & & $63 \mathrm{C}$ & & & \\
\hline tzpatric & & 780 & 1050 & 1050 & \begin{tabular}{|l|l|}
630 \\
\end{tabular} & 0 & 690 & 630 & 900 & 690 & \begin{tabular}{|l|}
450 \\
\end{tabular} & 630 & & \begin{tabular}{|l|l|}
420 \\
\end{tabular} & 99 & 660 & 570 & 90 & 810 & 840 & 10 & 1050 & 690 & 10 & 80 & 810 & 900 & & 102 & 810 & 930 & 900 & 750 & 750 & 750 & 780 & 780 & 690 & & & & 33 & 57 & 45 & 0 & 0 \\
\hline tzpatric & & 780 & 30 & 930 & 660 & 0 & 780 & 930 & 050 & 1050 & 540 & 00 & 660 & 600 & 60 & 35 & 540 & 40 & 660 & 930 & 60 & 930 & 660 & 780 & 660 & 930 & 750 & 660 & 1050 & 780 & \begin{tabular}{|l|l|}
780 \\
\end{tabular} & 1050 & 750 & 750 & & 660 & 660 & & & & 4 & 54 & 54 & 54 & 0 & 0 \\
\hline & & 900 & & & & & & & 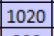 & 220 & & & & 50 & & & 46 & & & & & & 90 & & & & & & & & & & 900 & & & & & & & & & & & & & \\
\hline & & 900 & & & & & & & & & & & & & & & & & & & & & & & & & & & & & & & & & & & & & & & & & & & & \\
\hline itzpa & & 780 & & & & & 750 & & & 810 & & & & \begin{tabular}{|l|}
900 \\
\end{tabular} & & & 1020 & & & & & & & & & & & & & & & & & & & & & & & & & & 630 & & & \\
\hline itzpat & & 780 & \begin{tabular}{|l|}
93 \\
\end{tabular} & & 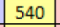 & & 690 & $E$ & 840 & 900 & | & & & 1020 & & & 1230 & 60 & & 109 & 63 & 80 & 450 & 900 & & 810 & & & 114 & 310 & 930 & \begin{tabular}{|l|l|l|l|l}
1260 \\
\end{tabular} & 900 & 90 & 900 & & 780 & 7 & & 696 & 59 & 75 & $63 \mathrm{C}$ & . & 66 & \\
\hline tzpat & & 780 & 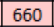 & & 450 & & 690 & & 900 & 840 & \begin{tabular}{|l|l|}
780 \\
\end{tabular} & 100 & 80 & \begin{tabular}{|l|l|}
900 \\
\end{tabular} & & 660 & 1020 & 000 & 630 & 630 & 109 & 540 & 510 & . & & 720 & 900 & & 10 & t & \begin{tabular}{|l|l|}
660 \\
\end{tabular} & \begin{tabular}{|l|l|}
9000 \\
\end{tabular} & 750 & 750 & 756 & 540 & 540 & & & & & 30169 & 630 & 51 & & \\
\hline tzpat & & 930 & & & & & 930 & 5 & 50 & 1050 & \begin{tabular}{|l|}
930 \\
\end{tabular} & & 50 & \begin{tabular}{|l|}
900 \\
\end{tabular} & 050 & 30 & 1050 & 50 & & 780 & 540 & 35 & 780 & & & 1050 & & & 105 & & 301 & & 750 & & & 78 & & & & & & & 66 & & & \\
\hline tzpa & & 690 & & & & & 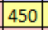 & & , & 750 & E & & & 750 & 990 & 60 & \begin{tabular}{|l|}
900 \\
\end{tabular} & & & 45 & 10 & 780 & \begin{tabular}{|c|}
109 \\
\end{tabular} & 0 & $t$ & 540 & & & $9 c$ & \begin{tabular}{|l|l|}
540 \\
\end{tabular} & 660 & & 630 & & & & & & & & & & \begin{tabular}{l|l}
0 & 450 \\
\end{tabular} & & & \\
\hline & & 900 & & & & & & & & & & & & & & & & & & & & & & & & & & & & & & & & & & & & & & & & & & & & \\
\hline & & 660 & & & & & & & & & & & & 50 & & & 30 & & & & & & & & & & & & & & & & & & & & & & & & & & & & & \\
\hline pat & & 900 & & & & & 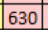 & & & & & & & & & & 1140 & & & & & & 540 & & & 65 & 570 & & 117 & & & & 870 & & & & & & & & & & & & & \\
\hline zpat & & 630 & 750 & 750 & & & 630 & & & 900 & 750 & 50 & & \begin{tabular}{|l|}
750 \\
\end{tabular} & & 750 & 1020 & 220 & & 102 & 900 & 750 & 750 & 510 & & 57 & & & 90 & 720 & & $t 6$ & & & & 180 & & & & & & & 3 & & & \\
\hline troa & & 660 & & & & & 660 & & & 930 & e & & & \begin{tabular}{|l|}
750 \\
\end{tabular} & & 660 & \begin{tabular}{|l|}
930 \\
\end{tabular} & 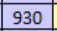 & & 78 & & & $L^{2}$ & & & 54 & & & 900 & & & 900 & & & & & & & & & & & 이 & & & \\
\hline & & 750 & & & & & & & & & 15 & & & \begin{tabular}{|l|l|}
90 \\
\end{tabular} & & & & & & & & & 9 & & & & & & & & & & 750 & & & & & & & & & & 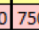 & & & \\
\hline & & 780 & & & & & & & & & & & & & & & & & & & & & & & & & & & & & & & & & & & & & & & & & & & & \\
\hline & & 780 & & & & & & & & & & & & & & & & & & & & & & & & & & & & & & & 750 & & & & & & & & & & & & & \\
\hline & & 900 & & & & & if & & & & & & & & & & & & & & & & & & & & & & & & & & 900 & & & & & & & & & & 90 & & & \\
\hline & & & & & & & & & & 5 & I & & & & & & 0 & & & 900 & & 50 & 630 & & & 8 & & & & & & 0 & 43 & & & & & & & & & & & & & \\
\hline & & & & & & & & & & & & & & & & & & & & & & & & & & & & & & & & & 420 & & & & & & & & & & & & & \\
\hline & & & & & & & & & & & & & & & & & $\begin{array}{ll}90 \\
\end{array}$ & & & 9 & & & & & & & & & & & & & 510 & & & & & & & & & & & & & \\
\hline & & 0 & & & & & & & & 9 & & & & & & & 93 & & & & & & 54 & & & & & & & & & & & & & & & & & & & & & & & \\
\hline & & 66 & & & & & & & & & & & & & & & & & & & & & & & & & & & & & & & & & & & & & & & & & & & & \\
\hline & & 78 & & & & & & & & & & & & & & & & & & & & & & & & & & & & & & & & & & & & & & & & & & & & \\
\hline & & & & & & & & & & & & & & & & & & & & & & & & & & & & & & & & & & & & & & & & & & & & & & \\
\hline & & & & & & & & & & & & & & & & & & & & & & & & & & & & & & & & & & & & & & & & & & & & & & \\
\hline & & & & & & & & & & & & & & & & & & & & & & & & & & & & & & & & & & & & & & & & & & & & & & \\
\hline & & 450 & & & $f$ & & & & & 0 & {$[2$} & & 6 & 4 & & & 690 & & & 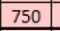 & & & 570 & & & 0 & & & & 50 & & 04 & 420 & & & & & & & & & & $\frac{5}{5}$ & & & \\
\hline & & 570 & & & & & & & & & & & & & & & & & & & & & & & & & & & & & & & & & & & & & & & & & & & & \\
\hline & & & & & & & & & & & & & & & & & & & & & & & & & & & & & & & & & & & & & & & & & & & & & & \\
\hline & & & & & & & & & & & & & & & & & & & & & & & & & & & & & & & & & & & & & & & & & & & & & & \\
\hline & & & & & & & & & & 6 & & & & & & & & & & & & & & & & & & & & & & & & & & & & & & & & & & & & \\
\hline & & 420 & & & & 0 & & & & 0 & & & & & & & \begin{tabular}{|c|}
750 \\
\end{tabular} & & & & & & & & & & & & & & & & 20 & & & & & & & & & & & & & \\
\hline & & ti & & & & & & & & & & & & & & & 7750 & & & & & & & & & & & & & & & & & & & & & & & & & & & & & \\
\hline & & & & & & & & & & & & & & & & & & & & & & & & & & & & & & & & & & & & & & & & & & & & & & \\
\hline & & & & & & & & & & & & & & & & & & & & & & & & & & & & & & & & & & & & & & & & & & & & & & \\
\hline & & & & & & & & & & & & & & & & & & & & & & & & & & & & & & & & & & & & & & & & & & & & & & \\
\hline $\mathrm{M} 269$ & & 690 & 930 & 930 & \begin{tabular}{|c|}
450 \\
\end{tabular} & 690 & 690 & 630 & 810 & 570 & \begin{tabular}{|c|}
690 \\
\end{tabular} & 750 & 660 & \begin{tabular}{|l|}
510 \\
\end{tabular} & 0 & 780 & 690 & 0 & 750 & \begin{tabular}{|l|}
840 \\
\end{tabular} & 10 & 930 & 690 & 750 & \begin{tabular}{|l|l|}
660 \\
\end{tabular} & 630 & 750 & 10 & 630 & 50 & 540 & 510 & & & & & & & & & & & & & & \\
\hline
\end{tabular}

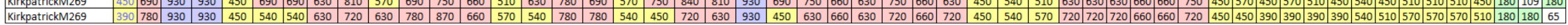

C) Copyright 2020 | All rights reserved I The Fitzpatrick Clan Society

Fitzpatrick, I., Fitzpatrick, M. (2020). Colonial American Fitzpatrick Settlers, Part I: Making Sense of One Line. The Journal of the Fitzpatrick Clan

Society 1, 18-39. doi:10.48151/fitzpatrickclansociety00220, Ver2, 23 May 2021 